\title{
Pengaruh Corporate Gorvenance Islam terhadap Tax Avoidance
}

\author{
Yusvita Nena Arinta \\ IAIN Salatiga \\ yusvitanenaarinta@gmail.com
}

\begin{abstract}
Abstrak
The purpose of the study was to investigate the effect of Islamic corporate governance on tax avoidance of sharia banking in Indonesia. The data that used in this study is scendary data derived from annual financial statements and good corporate governance report of sharia banking in Indonesia during 2013-2017 period. The number of sharia banking that became sample in this study were 8 banks so there 55 research samples. The metohod of analysis that use is multiple regression analysis. The results of this study show that the elements of corporate governance that consist of the board of commissioners, the board of commissioner meeting, the board of sharia, the board of sharia meeting, audit committee, meeting of audit comitte significantly influence the activity of tax avoidance as measured using proxy book tax gap. Other results show that the tax avoidance activity as measured with proxy book tax gap are not affected significantly by the board of commissioner meeting. Limitation of this study is use corporate governance's proxy separately, so it can't capture the full effect of corporate governane.
\end{abstract}

Keyword : Islamic corporate governace, tax avoidance, corporate governance

\section{A. PENDAHULUAN}

\section{Latar Belakang}

Pajak merupakan sumber yang dominan sebagai penopang pendapatan anggaran negara yang memainkan peran penting dalam hal pembiayaan belanja negara. Di Indonesia, pendapatan dari sektor pajak menempati persentase tertinggi dibandingkan dengan sumber pendapatan lain. (Tandean, 2016). Pajak sebagai kontribusi wajib kepada negara yang terutang oleh wajib pajak pribadi atau wajib pajak badan. Sebagai wajib pajak dengan tidak mendapatkan manfaat timbal balik secara langsung dan pemungutannya bersifat paksaan yang dilakukan berdasarkan undang-undang.

Pajak yang dibayarkan kepada pemerintah merupakan biaya yang mengurangi pendapatan atau laba bersih. Hal ini mengakibatkan mucul tindakan moral hazard yang dilakukan oleh perusahaan. Motif perusahaan melakukan praktek tersebut adalah untuk memaksimalkan keuntungan para pemegang saham. Perusahaan berusaha untuk membayar pajak seminimal mungkin, sedangkan bagi pemerintah menginginkan pajak semaksimal mungkin guna untuk membiayai penyelenggaraan pemerintahan. Terjadi konflik of interest antara perusahaan dan pemerintah yang menyebabkan wajib pajak cenderung untuk mengurangi jumlah pajak yang dibayarkan, baik secara legal maupun illegal. Perusahaan merupakan salah satu wajib pajak yang memberikan kontribusi terbesar dalam penerimaan pajak negara. Perusahaan akan berusaha mengelola beban pajaknya seminimum mungkin agar memperoleh laba yang maksimal. Usaha pengurangan pembayaran pajak secara legal disebut penghindaran pajak (tax avoidance), sedangkan usaha pengurangan pembayaran pajak secara ilegal disebut tax evasion (I Gede Hendy Darmawan, 2014). 
Tax avoidance merupakan suatu strategi pajak yang agresif yang dilakukan oleh perusahaan dalam memimalkan beban pajak, sehingga kegiatan ini memunculkan resiko bagi perusahaan antara lain denda dan buruknya reputasi perusahaan dimata public (Kurniasih, 2012). Praktek pembayaran efisiensi pajak seperti penghindaran pajak berakibat pada berkurangnya pendapatan negara guna pembiayaan belanja negara.Pemerintah mengharapkan sikap kepatuhan pajak masyarakat atau entitas. Ini termasuk sikap wajib pajak yang taat pajak yang menunjukkan bahwa pembayar pajak selalu membayar pajak sesuai dengan kondisi aktual yang akan meningkatkan pendapatan negara. Walaupun dalam upaya penghindaran pajak tersebut masih sesuai dengan ranah Undang Undang yang berlaku atau legal, pemerintah tidak mengiinginkan hal tersebut.

Fenomena perbedaan kepentingan antara wajib pajak dengan pemerintah dan rata-rata rasio pajak yang belum mencapai target dapat mengindikasikan adanya aktivitas penghindaran pajak yang cukup besar, sehingga penerimaan pajak negara Indonesia masih belum optimal.Selain dituntut untuk membayar pajak sebagai kewajiban, perusahaan-perusahaan go public di Indonesia juga diharuskan untuk menerapkan corporate governance. Dengan adanya mekanisme corporate governace dalam perusahaan, diharapkan mampu mempublikasikan laporan keuangan dengan transparan dan actual. Laporan keuangan yang actual dan transparan adalah laporan keuangan yang memuat laba sesuaid dengan realita. Karena perhitungan pajak yang dilaporkan oleh wajib pajak merupakan presentase dari laba.

Tunggakan Pajak pada BNI Syariah atas transaksi melalui akad Murabahah yang terjadi sekitar tahun 2007 dengan jumlah sekitar Rp 128,2 Miliar dengan PPN Murabahah sebesar Rp 128,8 Miliar plus sanksi administrasi Rp 20 Miliar ( Direktur BNI Ahmad Baequni pada diskusi Asosiasi Perbankan Syariah Indonesia (Asbisindo) di Jakarta, Selasa (2/2/2010). Kasus perpajakan yang menimpa BNI syariah yang seharusnya melakukan usaha sesuai dengan prinsip syariah ternyata melanggar beberapa prinsip syariah yaitu mendzolimi pihak lain yang dalam hal ini adalah Negara yang dirugikan akibat pajak tertunggak.

Melihat Fenomana tidak syari'ahnya bank syari'ah, maka Bank Indonesia dan para ulama ekonomi syari'ah harus melakukan purifikasi (pemurnian) prinsip syariah di dalam praktek perbankan syariah (Endraswati, 2017). Cara meningkatkan kemurnian prinsp syariah agar Bank Syariah tetap patuh terhadap prinsip dankode etik syariah serta dapat meminimalkan resiko yang timbul sebaga lembaga keuangan yang memiliki atribugt syariah adalah dengan menerapkan corporate governance (CG) yang harus benar-benar merujuk kepada prinsip dan nilai ekonomi dan bisnis Islam yang telah diterapkan oleh Rasulullah yang identik dengan spirit Is/amic Corporate Governance (ICG) yang dikembangkan dalam penelitian ini. Karena itu, penelitian tentang ICG sangat penting untuk dilakukan.

Penelitian ini meneliti tentang pengaruh ICG melalui strukturnya terhadaptax avoidance yang terjadi pada Bank Syariah. Struktur ICG yang dimaksud dalam penelitian ini merujuk pada Dewan Komisaris, Komite Audit dan Dewan Pengawas Syariah dalam menjalankan tugasnya pada bank syariah. Ketiga bagian board ini menjalankan fung si pengawasan pada perusahaan. Fungsi pengawasan ini bertujuan agar apa yang dilakukan perusahaan sesuai dengan prinsip dan kode etik dari Bank Syariah. Struktur ICG yang di teliti dalam penelitian ini meliputi proporsi Komisaris Independen, jumlah meeting Dewan Komisaris, ukuran Komite Audit, jumlah meeting 
Komite Audit, ukuran Dewan Pengawas Syariah, latar belakang pendidikan Dewan Pengawas Syariah, dan jumlah meeting Dewan Pengawas Syariah.

\section{Kerangka Teori}

\section{a. Teori Agency}

(Jensen and Meckling, 1976)menjelaskan hubungan agensi terjadi ketika satu atau lebih orang (principal) mempekerjakan orang lain (agen) untuk menyediakan layanan dan mendelegasikan otoritas untuk pengambilan keputusan. Teori agensi mengasumsikan bahwa setiap manusia egois dan memusatkan diri pada basis individualnya. Teori agensi juga menyiratkan bahwa ada asimetri informasi antara manajer sebagai agen dan prinsipal. Manajer perusahaan harus lebih sadar akan informasi internal sehingga akan ada ruang informasi antara manajemen dan pemilik perusahaan.. Manajemen secara moral bertanggung jawab untuk mengoptimalkan manfaat dari pemegang saham (dan untuk memuaskan kepentingan pribadi untuk memaksimalkan pemenuhan ekonomi dan psikologis). Pemegang saham di sisi lain, akan fokus pada peningkatan nilai sahamnya. Dengan demikian ada dua kepentingan yang berbeda dalam perusahaan di mana masing-masing pihak berusaha untuk mencapai atau mempertahankan tingkat kemakmuran yang diinginkan. Adanya konflik kepentingan antara keduanya inilah yang memicu munculnya teori agensi (Rusydi dan Martani, 2014). Oleh karena itu, untuk tujuan pemilik manajemen, pemilik saham harus memberikan insentif yang sesuai untuk memotivasi agen dalam hal melakukan pengawasan guna mencegah situasi yang tidak diinginkan (Jensen dan Meckling, 1976). Konflik agen dapat mempengaruhi perlakuan pajak agresif (Tandean, 2016). Masalah keagenan mungkin terjadi ketika ada perbedaan dalam kepentingan agen dan ketika pemilik saham memiliki perilaku penghindaran pajak yang agresif. Kondisi ini terjadi karena, manajemen ingin meningkatkan kompensasi melalui laba yang lebih tinggi, sedangkan pemegang saham lainnya ingin mengurangi biaya pajak melalui laba yang lebih rendah.

\section{b. Tax Avoidance}

Tax Avoidance adalah situasi ketika perusahaan melakukan kebijakan pajak tertentu dan ada kemungkinan bahwatindakan pajak tidak akan diaudit atau dipertanyakan dari sudut pandang hukum, tetapi tindakannya berisiko, jika tindakan pajak dianggap melanggar hukum (Hite dan McGill dalam Sari dan Martani 2010). Pemilik perusahaan cenderung memilih perusahaan untuk bertindak agresif dalam menghindari pajak karena biaya pajak (Chen et al., 2010). Komite urusan fiskal Organization for Economic Cooperation and Development (OECD) di Suandy (2008) menyatakan bahwa ada tiga karakteristik dalam penghindaran pajak, yaitu:

1) Banyak peraturan yang mengabaikan faktor pajak.

2) Mengambil keuntungan dari celah peraturan hukum untuk tujuan pribadi tetapi tidak diinginkan oleh regulator.

3) Konsultan pajak menunjukkan bagaimana menghindari pajak dan meminta pembayar pajak untuk merahasiakannya.

\section{c. Mekanisme Corporate Governance}

Walsh dan Seward (1990) berpendapat bahwa terdapat dua mekanisme untuk memperkecil perbedaan kepentingan antara pemegang saham dan manajer 
dalam rangka penerapan CG, yaitu: (1) mekanisme pengendalian internal perusahaan, dan (2) mekanisme pengendalian eksternal. Lukviarman (2007) sejalan dengan pernyataan di atas bahwa mekanisme Corporate Governance dapat dikategorikan secara umum berdasarkan karakteristiknya sebagai bagian internal atau eksternal dari sebuah korporasi. Penelitian ini lebih berkaitan dengan mekanisme internal perusahaan. Karena Corporate Governancedan kualitas laporan keuangan bagian dari mekanisme internal perusahaan.

d. Corporate Governance Islam

Menurut Najmudin (2011) dalam Endraswati (2016) corporate governance dalam Islam adalah sistem yang mengarahkan dan mengendalikan perusahaan untuk memenuhi tujuan perusahaan dengan melindungi kepentingan dan hak semua stakeholder dengan menggunakan konsep dasar pengambilan keputusan berdasarkan epistemologi sosial-ilmiah Islam yang didasarkan pada ketauhidan Allah. Menurut Bhatti dan Bhatti (2009) Islamic Corporate Governance mempertimbangkan efek hukum syariah dan prinsip ekonomi dan keuangan Islam pada praktek dan kebijakan, misalnya pada lembaga zakat, pelarangan spekulasi, dan pengembangan sistem ekonomi yang didasarkan pada bagi hasil. Pengambilan keputusan yang dilakukan melebihi konteks corporate governance konvensional yang mencakup pemegang saham, supplier, kreditur, konsumen, pesaing, dan karyawan (Lewis, 2006). Tujuan utama Islamic Corporate Governance aYudalah Maqasid Shariah yang merujuk pada kesejahteraan masyarakat (Hasan, 2008). Istilah Shariah Governancemerujuk pada istilah ISFB-10 (2009) yang menyatakan bahwa 'a set of institutional and organisational arrangements through which Islamic financial institution ensure that there is an effective independent oversight of shariah compliance over the issuence of relevant shariah pronouncements, dissemination of information and an internal shariah compliance review'. Rama dan Novella (2015) menguraikan definisi tersebut menjadi tiga komponen utama yaitu: adanya Dewan Pengawas Syariah dalam struktur organisasi, adanya opini yang bersifat independen kaitannya dengan pelaksanaan fungsi kepatuhan pada syariah, dan proses review pada pemenuhan syariah. Dato' Mustapa Muhammed dalam Hassan, Saifuddeen, dan Salleh (2002) menyebutkan bahwa ide corporate governance merupakan budaya perusahaan yang ada pada nilai-nilai Qur'an seperti kejujuran, kepercayaan, dan transparansi. Menurut Hassan et al. (2002) tiga komponen utama dalam budaya perusahaan Islam adalah tanggung jawab sosial pada bisnis, keadilan, dan kerjasama antar anggota masyarakat. Raja Dato' Arshad Raja Tun Uda dalam Hassan et al. (2002) menyatakan bahwa budaya perusahaan yang ada di Malaysia bersumber pada dua prinsip utama yaitu: prosperity dan corporate accountability. Corporate Governance di Malaysia menurut Tan Sri Nik Mohamed Nik Menurut Endraswati (2016) hal yang membedakan corporate governance di perbankan syariah dibandingkan dengan perbankan konvensional adalah hadirnya Dewan Pengawas Syariah dalam struktur corporate governancenya. Mekanisme yang membedakan antara perusahaan konvensional dan syariah adalah mekanisme pengambilan keputusan. Pengambilan keputusan dalam perusahaan syariah didasarkan pada hukum Islam yaitu Al Qur'an dan Sunah Rasullullah saw, sedangkan perusahaan dengan corporate governance konvensional lebih menekankan kesesuaian dengan undang-undang dan peraturan pemerintah. Selain itu empat sifat wajib rasul yaitu 
shiddiq, amanah, tabligh, dan fathonah menjadi sifat kepemimpinan dalam Islam (Arief, 2014). Karena itu pula, empat sifat wajib rasul tersebut dijabarkan dalam aplikasi Islamic Corporate Governance yang didasarkan pada hukum Al Qur'an dan Hadist. Loredana, Alexandru dan Roxana (2016) menyatakan bahwa konsep corporate governance dalam Model Islam menjelaskan bahwa manajer dan auditor bekerja secara profesional, memiliki tujuan untuk memenuhi kepentingan pemegang saham dan aturan Allah swt.

\section{B. Pengembangan Hipotesis}

\section{Proporsi Dewan Komisaris Independen terhadap tax fraudulent}

Komisaris dalam struktur manajemen adalah tingkat tertinggi setelah pemegang saham. Dewan Komisaris memegang peran sentral dalam tata kelola perusahaan karena perusahaan memiliki tanggung jawab hukum untuk fokus pada urusan perusahaan pada dewan komisaris ketika perusahaan menetapkan tujuan, mengembangkan kebijakan yang komprehensif, dan memilih personil tingkat atas untuk melaksanakan tujuan dan kebijakan. Dewan Komisaris sebagai dewan yang bertanggung jawab atas perusahaan secara kolektif bertanggung jawab untuk mengawasi dan meninjau kinerja manajemen untuk memastikan bahwa perusahaan dijalankan dengan baik dan kepentingan pemegang saham dilindungi. Dewan Komisaris juga memberikan saran kepada Dewan dan memastikan bahwa Perusahaan menerapkan Tata Kelola Perusahaan yang Baik (KNKG, 2006). Apabila tidak ada pengawasan dari Komisaris Independen, maka akan semakin besar kemungkinan eksekutif yang lain dapat memanipulasi posisi mereka dengan mendapatkan kontrol yang penuh atas remunerasi mereka sendiri dan mengamankan jabatan mereka (Solomon 2007), sehingga dapat merugikan pemegang saham. Sebaliknya, semakin besar Proporsi Komisaris Independen, maka akan dapat meningkatkan kinerja dan kekayaan pemegang saham (Minnick dan Noga 2010). Sedangkan dari perspektif stakeholder, keberadaan Komisaris Independen dalam perusahaan merupakan strategi stakeholder untuk ikut memberi pengaruh dan mengawasi perusahaan sehingga memberi keuntungan bagi stakeholder. Beberapa penelitian terdahulu menemukan bahwa Proporsi Komisaris Independen berpengaruh negatif dan signifikan terhadap tax avoidance

$\mathrm{H}_{1}$ : Proporsi Komisaris Independen berpengaruh signifikan terhadap tax avoidance

\section{Rapat Dewan Komisaris terhadap tax fraudulent}

Salah satu tanggung jawab Dewan Komisaris adalah menghadiri rapat dan mereka dapat menyalurkan hak suaranya melalui rapat tersebut (Ronen dan Yaari, 2008). Suhardjanto dan Anggitarani (2010) menyatakan bahwa semakin sering rapat Dewan Komisaris, maka ke kurang sesuaian pelaksanaan perusahaan akan semakin cepat terdeteksi. Hal ini sejalan dengan apa yang di ungkapkan oleh Chen dan Zhou (2006) yang menyatakan bahwa frekuensi rapat Dewan komisaris mengurangi kemungkinan terjadinya fraud karena rapat yang teratur memungkinkan dewan komisaris untuk mengidentifikasi dan memecahkan masalah yang ada. Ntim dan Osei (2011) membuktikan dan mendukung teori keagenan, serta menunjukkan bahwa Dewan Komisaris perusahaan yang lebih sering melakukan rapat akan meningkatkan kapasitasnya dalam menyarankan dan memantau manajemen. Dewan komisaris yang sering tidak mengagendakan rapat akan dengan mudah untuk tertinggal informasi dan tidak melakukan penelusruan lebih jauh atyas apa yang dialami perusahaan, Dewan Komisaris hanya melakukan persetujuan atas kegiatan yang dilakukan manaemen. 


\section{$\mathrm{H}_{2}$ : Rapat Dewan Komisaris berpengaruh signifikan terhadap tax avoidance}

\section{Dewan Pengawas Syariah terhadap tax fraudulent}

Menurut Rahman dan Bukhair (2013) semakin besar jumlah anggota Dewan pengawas syariah maka akan semakin efektif monitoring dan konsistensi pada prinsip syariah, semakin besar kemampuannya dalam mengontrol transaksi pada perbankan syariah dengan melihat kesesuaiannya dengan prinsip syariah sehingga berpengaruh pada kualitas pengungkapan. Hipotesis penelitiannya adalah:

$\mathrm{H}_{3}$ :Ukuran Dewan Pengawas Syariah berpengaruh signifikan pada Tax Avoidance

\section{Rapat Dewan pengawas Syariah terhadap tax fraudulent}

Menurut Bukair (2014) efektifitas Dewan pengawas syariah berpengaruh pada pengungkapan informasi. Semakin sering rapat maka fungsi pengawasan yang dilakukan DPS kaitannya dengan kesesuaian syariah dan kualitsa pengungkapan akan semakin baik. Kualitas pengungkapan laporan keuangan yang baik akan memanfaatkan dengan baik tax avoidance. Maka dari itu hipotesis penelitiannya adalah:

\section{$\mathrm{H}_{4}$ : Jumlah Rapat Dewan Pengawas Syariah berpengaruh signifikan terhadap tax avaoidance}

\section{Latar belakang Dewan Pengawas Syariah terhadap tax fraudulent}

Pengetahuan dan pengalaman merupakan elemen yang signifikan untuk memastikan efektivitas fungsi monitoring dewan komisaris (Alzaubi, 2012). Menurut Farook (2011) bahwa latar belakang pendidikan berpengaruh pada praktek pengungkapan. Selain itu, pendidikan menentukan tingkat profesionalitas (Grace, Ireland, dan Dunstan, 1995). Menurut Rahman dan Bukhair (2013) anggota Dewan Pengawas Syariah harus memiliki pengetahuan hukum Islam, ekonomi, keuangan dan akuntansi. Jenjang pendidikan doktoral memiliki implikasi yang lebih baik pada pengungkapan. Alzaubi (2012) menyatakan pula bahwa pengetahuan tentang akuntansi dan keuangan berguna bagi Dewan Pengawas Syariah untuk memahami laporan keuangan yang lebih baik. Hipotesis penelitiannya adalah:

$\mathrm{H}_{5}$ : Latar Belakang Dewan Pengawas Syariah berpengaruh signifikan terhadap Tax Avoidance

\section{Komite Audit terhadap tax fraudulent}

Komite Audit adalah komite yang dibentuk oleh dan bertanggung jawab kepada Dewan Komisaris. Perusahaan publik harus memiliki Komite Audit yang bertindak independen dalam melaksanakan tugas dan tanggung jawabnya. Anggota Komite Audit diangkat dan diberhentikan oleh Dewan Komisaris (BAPEPAM-LK, 2012). Komite audit bertanggung jawab memastikan bahwa perusahaan telah dijalankan sesuai dengan hukum dan peraturan, telah melakukan bisnis dengan etika, menerapkan kontrol terhadap konflik kepentingan dan penipuan yang dilakukan oleh karyawan perusahaan. Salah satu elemen penting dalam tata kelola perusahaan adalah keterbukaan informasi yang terbuka bagi semua pihak yang berkepentingan. Dengan adanya transparansi dalam pengelolaan perusahaan, dapat melemahkan pajak agresif sehingga menghindari pajak. Komite Audit memiliki pengaruh yang bermakna terhadap pengindaran pajak atau tax avoidance (Maharani dan Suardana 2014; Dewi dan Jati 2014; Annisa dan Kurniasih 2012).

$\mathrm{H}_{6}$ : Komite Audit berpengaruh signifikan terhadap tax avoidance

\section{Jumlah Rapat Komite Audit terhadap tax fraudulent}


Komite Audit menjalankan tugasnya melalui rapat dan aktivitas auditing perusahaan. Semakin sering rapat, berarti semakin sering melakukan monitoring in ternal termasuk dalam hal transparansi. Semakin tinggi intensitas pertemuan yang diadakan me mungkinkan komite audit secara intens membahas tentang hal-hal penting pada penyusunan laporan ke uangan. Alzoubi (2012) menyatakan bahwa Komite Audit yang melakukan rapats secara reguler pada tahun fiskal di asosiasikan dengan monitoring yang efektif. Semakin sering mereka bertemu semakin efisien mereka dalam menjalankan tanggungj awabnya. Frekuensi rapat diduga berpengaruh pada tax avoidance, sehingga hipotesisnya adalah:

\section{$\mathrm{H}_{7}$ : Rapat Komite Audit berpengaruh signifikan terhadap tax avoidance.}

\section{Metode}

1. Populasi

Populasi penelitian ini adalah semua bank umum syariah yang ada di Indonesia. Jumlah bank umum syariah sampai pada tahun 2017 ada 11 bank syariah. Sampel

2. Sampel

Sampel penelitian adalah semua perbankan syariah yang ada di Indonesia yang memiliki data yang diperlukan dalam penelitian ini. Jumlah sampel dalam penelitian ini 11 bank umum syariah dengan periode penelitian $2013-2017$.

\section{Teknik Pengumpulan Data}

Data dalam penelitian ini menggunakan data sekunder. Data penelitian diperoleh melalui annual report masingmasing perbankan syariah di Indonesia.

\section{Definisi dan Operasional Variabel}

\section{Tax Avoidance (TA)}

Tax avoidance adalah usaha untuk mengurangi, atau bahkan meniadakan hutang pajak yang harus dibayar perusahaan dengan tidak melanggar undang-undang yang ada. Variabel ini di proksikan dengan menggunakan rumus Tarif Pajak Efektif (ETR). Tarif pajak efektif digunakan sebagai pengukuran karena dianggap dapat merefleksikan perbedaan tetap antara perbedaan laba buku dan laba fiskal. Tarif Pajak Efektif (ETR) dihitung dengan menggunakan cara membagi total beban pajak perusahaan dengan laba sebelum pajak penghasilan.

$$
\mathrm{ETR}=\frac{\text { Beban Pajak }}{\text { Lab sebelum Pajak }}
$$

\section{Proporsi Komisaris Independen}

Komisaris independen adalah anggota dewan komisaris yang tidak terafiliasi dengan manajemen, anggota komisaris lainnya dan pemegang saham pengendali.

$$
\text { PKI }=\frac{\text { Jumlah } \text { Komisaris Independen }}{\text { Komisaris }}
$$

\section{Jumlah Rapat Dewan Komisaris}

Jumlah meeting Dewan Komisaris adalah jumlah rapat yang dilakukan oleh anggota Dewan Komisaris dalam perusahaan selama satu tahun. 


$$
\text { JRDK }=\sum \text { Rapat Komisaris dalam setahun }
$$

\section{Jumlah Dewan Pengawas Syariah}

Ukuran Dewan Pengawas Syariah adalah jumlah seluruh Dewan Pengawas Syariah yang melakukan pengawasan syariah pada perbankan syariah. Peraturan Bank Indonesia Nomor 6/24/PBI/2004 pasal 26 (1) menyatakan bahwa jumlah anggota Dewan Pengawas Syariah paling kurang 2 (dua) orang dan sebanyak-banyaknya 5 (lima) orang.

$$
\text { JDPS }=\sum \text { Dewan Pengawas Syariah }
$$

\section{Jumlah Rapat Dewan Pengawas Syariah}

Peraturan mengenai rapat Dewan Pengawas Syariah juga diatur dalam PBI Nomor 11/33/PBI/2009 Pasal 49 yang menyatakan bahwa rapat Dewan Pengawas Syariah wajib diselenggarakan paling kurang satu (1) kali dalam satu (1) bulan.

JRDPS $=\sum$ Rapat Dewan Pengawas Syariah

\section{Latar Belakang Dewan Pengawas Syariah}

Latar Belakang pendidikan Dewan Pengawas Syariah merupakan presentase jumlah seluruh anggota Dewan Pengawas Syariah yang memiliki latar belakang pendidikan syariah muamalah dan perbankan serta keuangan secara umum yang terdapat di perusahaan dibagi dengan jumlah seluruh Dewan Pengawas Syariah yang ada di perusahaan.

\begin{tabular}{c} 
LATBEL DPS = \\
$\frac{\text { DPS dengan pendidikan syariah,muamalah,perbankan,keuangan }}{\text { Jumlah DPS }}$ \\
\hline
\end{tabular}

\section{Jumlah Komite audit}

Ukuran Komite Audit merupakan jumlah seluruh anggota Komite Audit yang terdapat di perusahaan (Felo et al., 2003). PBI Nomor: 11/33/PBI/2009 mengatur bahwa keanggotaan Komite Audit sekurang-kurangnya terdiri dari 3 (tiga) orang anggota, seorang diantaranya merupakan Komisaris Independen perusahaan yang sekaligus merangkap sebagai ketua Komite Audit, sedangkan dua anggota lainnya merupakan pihak ekstern yang independen di mana satu diantaranya memiliki keahlian di bidang keuangan atau perbankan.

$$
\text { JKA }=\sum \text { Jumlah Komite Audit dalam setahun }
$$

\section{Jumlah Rapat Komite Audit}

Frekuensi rapat Komite Audit dalam setahun dapat mencerminkan seberapa jauh Komite Audit membantu Komisaris terlibat dalam mengawasi manajemen.

$$
\text { JKA }=\sum \text { Jumlah Rapat Komite Audit dalam setahun }
$$




\section{Analsisis Data}

Penelitian ini menggunakan teknik analisis regresi berganda karena tujuan penelitiannya adalah untuk menguji pengaruh variabel independen pada variabel dependennya. Model penelitian ini adalah

Tax Avoidance $($ TA $)=\mathbf{a 0}+$ b $_{1}$ PKI + b2 JRDK + b3 JDPS + b4JRDPS + b5LATBELDPS

$$
\text { + b6 JKA + b7 JRKA+ e }
$$

Pengujian hipotesis dengan melihat nilai t untuk melihat signifikansi pengaruh variabel independen terhadap variabel dependen. Apabila nilai signifikansi t lebih kecil dari derajat kepercayaannya yaitu 5\%, maka pengaruh variabel independen terhadap variabel dependen adalah signi fikan. Model yang baik menurut Ghozali (2005) dapat dilihat berdasarkan nilai adjusted $\mathrm{R}$ squared, nilai $\mathrm{t}$ dan nilai $\mathrm{F}$. Sebelum dilakukan pengujian hipotesis, dilakukan pengujian asumsi klasik. Uji asumsi klasik yang meliputi uji normalitas, uji multi kolinearitas, uji heterokedastisitas, dan uji autokorelasi perlu dilakukan terlebih dahulu sebelum analisis data dilakukan (Ghozali, 2005:56). Uji asumsi klasik ini untuk memenuhi BLUE (best linier unbiased estimation) dan kesimpulan yang dibuat dari hasil analisa regresi menjadi tidak bias (Hill, Griffiths, dan Judge, 2001).

\section{Hasil dan Pembahasan}

\section{Statistik Deskriptif}

Secara keseluruhan terdapat 55 data observasi perbankan selama tahun 20132017. Jumlah bank yang menjadi sampel penelitian ini berjumlah 11 bank syariah. Jumlah populasi perbankan syariah yang terdaftar di Bursa Efek Indonesia pada periode tersebut sejumlah 11 bank, sehingga semua populasi yang ada digunakan menjadi sampel dalam penelitian ini, sehingga sampel dalam penelitian ini merupakan sampel jenuh. 


\begin{tabular}{|c|c|c|c|c|c|}
\hline & $\mathrm{N}$ & Minimum & Maximum & Mean & Std. Deviation \\
\hline $\begin{array}{l}\text { Jumlah Dewan Komisaris } \\
\text { Independen }\end{array}$ & 55 & .50 & 1.00 & .5955 & .14978 \\
\hline $\begin{array}{l}\text { Jumlah Rapat Dewan } \\
\text { Komisaris }\end{array}$ & 55 & 8 & 88 & 19.20 & 11.393 \\
\hline $\begin{array}{l}\text { Jumlah Dewan Pengawas } \\
\text { Syariah }\end{array}$ & 55 & 2 & 4 & 3.09 & .519 \\
\hline $\begin{array}{l}\text { Jumlah Rapat Dewan } \\
\text { Pengawas Syariah }\end{array}$ & 55 & 9 & 19 & 14.80 & 2.407 \\
\hline Latar Belakang DPS & 55 & 0 & 0,3 & 0,10 & .000 \\
\hline Jumlah Komite Audit & 55 & 3 & 7 & 3.98 & .892 \\
\hline jumlah Rapat KOmite Audit & 55 & 10 & 31 & 15.05 & 3.391 \\
\hline Tax Avoidance & 55 & .2 & .4 & .269 & .0393 \\
\hline Valid N (listwise) & 55 & & & & \\
\hline
\end{tabular}

Berdasarkan Tabel 5.1 Statistik Deskriptif dapat diketahui bahwa proporsi Komisaris Independen pada perbankan syariah di Indonesia rerata 59,55\%. Regulasi di Indonesia khususnya GCG tentang Bank Syariah yaitu PBI Nomor 8/4/2006 pasal 5 menyatakan bahwa Dewan Komisaris terdiri dari Komisaris dan Komisaris Independen paling kurang 50\% (lima puluh perseratus) dari jumlah anggota Dewan Komisaris adalah Komisaris Independen. Hal ini menunjukkan bahwa proporsi Komisaris Independen pada perbankan syariah sudah sesuai dengan aturan yang berlaku.

Jumlah rapat Dewan Komisaris pada perbankan syariah di Indonesia rerata 19,20\%. Menurut PBI tahun 2006 bahwa rapat Dewan Komisaris wajib diselenggarakan secara berkala paling kurang 4 (empat) kali dalam setahun. Rapat Komisaris sebagaimana dimaksud pada ayat (1) wajib dihadiri oleh seluruh anggota Komisaris secara fisik paling kurang 2 (dua) kali dalam setahun. Dalam hal anggota Komisaris tidak dapat menghadiri rapat secara fisik, maka dapat menghadiri rapat melalui teknologi telekonferensi. Berdasarkan peraturan Bank Indonesia tersebut, Dewan Komisaris pada Bank Syariah di Indonesia aktif melaksanakan rapat untuk melakukan fungsi monitoring.

Ukuran Dewan Pengawas Syariah pada perbankan syariah di Indonesia rerata 3.09. Hal ini sudah sesuai dengan peraturan Bank Indonesia tahun 2004 yang menyatakan bahwa jumlah anggota Dewan Pengawas Syariah sekurangkurangnya dua orang dan sebanyak-banyaknya lima orang. Berdasarkan tabel tersebut di atas dapat diketahui bahwa minimal jumlah anggota Dewan Pengawas Syariah di Bank Syariah Indonesia sejumlah dua dan maksimal sejumlah empat orang.Berdasarkan peraturan Bank Indonesia tahun 2004 latar belakang pendidikan Dewan Pengawas Syariah adalah syariah muamalah, perbankan atau keuangan secara umum. Pada umumnya, latar belakang pendidikan Dewan Pengawas Syariah pada Bank Syariah di Indonesia berpendidikan syariah muamalah. Pendidikan Dewan Pengawas Syariah tentang perbankan dan keuangan secara umum masih terbatas. Dari hasil temuan ini dapat diketahui bahwa belum semua anggota Dewan Pengawas Syariah memliki latar belakang yang sesuai. Hasil temuan ini berbeda dengan hasil penelitian yang dilakukan oleh Rosiana, Arifin dan Hamdani (2015) yang meneliti latar belakang pendidikan Dewan Pengawas Syariah pada Bank Umum Syariah di Indonesia periode 2010-2012. Rosiana et al. (2015) menemukan bahwa semua anggota Dewan Pengawas Syariah sudah memiliki latar belakang Jurnal Bisnis dan Manajemen Islam 
pendidikan yang sesuai. Penelitian Grais dan Pellegreni (2006) mengungkap kelemahan mekanisme internal tata kelola perbankan syariah dengan responden pada bank syariah di 16 negara menemukan bahwa kompetensi Dewan Pengawas Syariah belum sesuai. Sementara itu, kelemahan mekanisme eksternal kaitannya dengan tata kelola bank syariah adalah penegakan regulasi yang ada masih lemah. Jumlah rapat Dewan Pengawas Syariah pada perbankan syariah di Indonesia rerata 14,80 . Hal ini sudah sesuai dengan PBI tahun 2009 pasal 49 yang menyatakan bahwa rapat Dewan pengawas Syariah wajib diselenggarakan paling tidak satu kali dalam satu bulan. Rerata jumlah rapatDewan Pengawas Syariah dalam penelitian ini sekitar 14-15 kali berarti sudah lebih dari 12 kali dalam satu tahun.Sementara Skor variable aktivitas pajak agresif atau tax avoidance di Bank Syariah yang ada di Indonesia mencapai rerata 0.296. Hal ini bermakna bahwa tingkat perilaku penghindaran pajak pada perusahaan perbankan syariah di Indonesia masih rendah (Syandi, Sendeila et al. 2014).

Ukuran Komite Audit pada perbankan syariah di Indonesia rerata 3,98 atau 3-4 jumlah komite audit. Hal ini sudah sesuai dengan PBI tahun 2006 yang menyatakan bahwa anggota Komite Audit sekurang-kurangnya tiga orang. PBI Nomor: 11/33/ PBI/2009 mengatur bahwa keanggotaan Komite Audit sekurang-kurangnya terdiri dari 3 (tiga) orang anggota, seorang diantaranya merupakan Komisaris Independen perusahaan yang sekaligus merangkap sebagai ketua Komite Audit, sedangkan dua anggota lainnya merupakan pihak ekstern yang independen di mana satu diantaranya memiliki keahlian di bidang keuangan atau perbankan. Selain itu Peraturan Bank Indonesia Nomor: 11/33/PBI/2013 mengatur bahwa keanggotaan Komite Audit sekurangkurangnya berjumlah 3 orang.

Jumlah Rapat Komite Audit pada perbankan syariah di Indonesia rerata 15,05. Peraturan Bank Indonesia yang mengatur tentang rapat Komite Audit belum rinci, namun menurut Blue Ribbon Committe (1999) bahwa rapat Komite Audit tidak kurang dari empat (4) kali dalam setahun. Berdasarkan tabel tersebut di atas dapat diketahui bahwa seluruh Ukuran Komite Audit pada perbankan syariah di Indonesia rerata 3,98 atau 3-4 jumlah komite audit. Hal ini sudah sesuai dengan PBI tahun 2006 yang menyatakan bahwa anggota Komite Audit sekurang-kurangnya tiga orang. PBI Nomor: 11/33/ PBI/2009 mengatur bahwa keanggotaan Komite Audit sekurang-kurangnya terdiri dari 3 (tiga) orang anggota, seorang diantaranya merupakan Komisaris Independen perusahaan yang sekaligus merangkap sebagai ketua Komite Audit, sedangkan dua anggota lainnya merupakan pihak ekstern yang independen di mana satu diantaranya memiliki keahlian di bidang keuangan atau perbankan. Selain itu Peraturan Bank Indonesia Nomor: 11/33/PBI/2013 mengatur bahwa keanggotaan Komite Audit sekurangkurangnya berjumlah 3 orang.

Jumlah Rapat Komite Audit pada perbankan syariah di Indonesia rerata 15,05. Peraturan Bank Indonesia yang mengatur tentang rapat Komite Audit belum rinci, namun menurut Blue Ribbon Committe (1999) bahwa rapat Komite Audit tidak kurang dari empat (4) kali dalam setahun. Berdasarkan tabel tersebut di atas dapat diketahui bahwa seluruh

2. Hasil Pengujian Asumsi Klasik

Tabel 4.2 Uji asumsi Klasik -Kolmgrof Smirnof 


\begin{tabular}{|c|c|c|c|c|c|c|c|c|}
\hline & & $\begin{array}{c}\text { Jumlah } \\
\text { Dewan } \\
\text { Komisari } \\
\text { s } \\
\text { Indepen } \\
\text { den }\end{array}$ & $\begin{array}{c}\text { Jumlah } \\
\text { Rapat } \\
\text { Dewan } \\
\text { Komisari } \\
\text { s }\end{array}$ & $\begin{array}{c}\text { Jumlah } \\
\text { Dewan } \\
\text { Penga } \\
\text { was } \\
\text { Syariah }\end{array}$ & $\begin{array}{c}\text { Jumlah } \\
\text { Rapat } \\
\text { Dewan } \\
\text { Pengawa } \\
\text { s Syariah }\end{array}$ & $\begin{array}{c}\text { Latar } \\
\text { Belakan } \\
\text { g DPS }\end{array}$ & $\begin{array}{c}\text { Jumla } \\
\mathrm{h} \\
\text { Komit } \\
\mathrm{e} \\
\text { Audit }\end{array}$ & $\begin{array}{c}\text { jumlah } \\
\text { Rapat } \\
\text { KOmit } \\
\text { e } \\
\text { Audit }\end{array}$ \\
\hline \multicolumn{2}{|l|}{$\mathrm{N}$} & 55 & 55 & 55 & 55 & 55 & 55 & 55 \\
\hline \multirow[t]{2}{*}{ Normal Parameters ${ }^{a}$} & Mean & .5955 & 19.20 & 3.09 & 14.80 & .3346 & 3.98 & 15.05 \\
\hline & $\begin{array}{l}\text { Std. } \\
\text { Deviatio } \\
n\end{array}$ & .14978 & 11.393 & .519 & 2.407 & .02278 & .892 & 3.391 \\
\hline \multirow{3}{*}{$\begin{array}{l}\text { Most Extreme } \\
\text { Differences }\end{array}$} & Absolute & .306 & .209 & .388 & .194 & .504 & .310 & .197 \\
\hline & Positive & .306 & .188 & .388 & .194 & .504 & .310 & .197 \\
\hline & Negative & -.262 & -.209 & -.340 & -.163 & -.420 & -.217 & -.129 \\
\hline \multicolumn{2}{|l|}{ Kolmogorov-Smirnov Z } & 2.270 & 1.551 & 2.875 & 1.438 & 3.739 & 2.299 & 1.463 \\
\hline \multicolumn{2}{|l|}{ Asymp. Sig. (2-tailed) } & .126 & .016 & .065 & .032 & .077 & .0122 & .028 \\
\hline
\end{tabular}

Pengujian normalitas bertujuan untuk mengetahui apakah data berdistribusi normal atau tidak (Hair et al., 2006:208). Berdasarkan hasil uji KS, dapat disimpulkan bahwa residual berdistribusi normal, yaitu dengan melihat nilai signifikansi yang jauh di atas 0,05.

\section{Uji Multikolinieritas}

Uji multikolinearitas bertujuan untuk menguji apakah model regresi ditemukan adanya korelasi antar variabel bebas (Gujarati, 2004:342). Metode analisis untuk menguji terjadinya multikolinearitas dapat diamati dari hasil nilai tolerance value atau variance inflation factor (VIF). Nilai tolerance tidak ada yang kurang dari $10 \%$ dan hasil perhitungan VIF (Variance Inflation Factor) yang menunjukkan bahwa tidak ada variabel yang memiliki VIF lebih dari 10 sehingga dapat disimpulkan bahwa variabel bebas tidak saling berkorelasi secara signifikan. Hasil pengujian ini menunjukkan bahwa, data yang dianalisis memenuhi asumsi multikolinearitas. 
Tabel 4.3 Uji Multikolinieritas

\begin{tabular}{|l|r|r|}
\hline \multirow{2}{*}{\multicolumn{1}{|c|}{ Model }} & \multicolumn{2}{|c|}{ Collinearity Statistics } \\
\cline { 2 - 3 } & \multicolumn{1}{c|}{ Tolerance } & \multicolumn{1}{c|}{ VIF } \\
\hline 1. (Constant) & .456 & \\
Jumlah Dewan Komisaris & 2.195 \\
Independen & .218 & 4.596 \\
Jumlah Rapat Dewan Komisaris & .470 & 2.126 \\
Jumlah Dewan Pengawas Syariah & .791 & 1.265 \\
Jumlah Rapat Dewan Pengawas & .239 & 4.185 \\
Syariah & .608 & 1.645 \\
Latar Belakang DPS & .408 & 2.451 \\
Jumlah Komite Audit & & \\
jumlah Rapat Komite Audit & & \\
\end{tabular}

\subsection{Uji Autokorelasi}

Uji autokorelasi bertujuan untuk menguji apakah dalam suatu model regresi linear tidak ada korelasi antara kesalahan pengganggu pada periode t dengan kesalahan pada periode t-1 (sebelumnya). Jika terjadi korelasi maka disebut dengan autokorelasi (Gujarati, 2004: 442). Penelitian ini menggunakan Uji DW. Nilai DW dalam penelitian ini 1,702 dengan du 1,193 dan dl 1,730. Menurut kriteria du dan 4-du, maka tidak terjadi autokeralasi dalam penelitian ini.

Tabel 4.4 Uji Autikorelasi

\begin{tabular}{|l|r|r|r|r|r|}
\hline Model Summary \\
\hline Model & R & R Square & $\begin{array}{c}\text { Adjusted R } \\
\text { Square }\end{array}$ & $\begin{array}{c}\text { Std. Error of } \\
\text { the Estimate }\end{array}$ & $\begin{array}{c}\text { Durbin- } \\
\text { Watson }\end{array}$ \\
\hline 1 & $.494^{\mathrm{a}}$ & 444 & .458 & .0366 & 1.702 \\
\hline
\end{tabular}

a. Predictors: (Constant), jumlah Rapat KOmite Audit, Jumlah Komite Audit, Jumlah Rapat Dewan Pengawas Syariah, Jumlah Dewan Pengawas Syariah, Latar Belakang DPS, Jumlah Dewan Komisaris

a. Dependent Variable: Tax Avoidance

\subsection{Uji Heterokedastisitas}

Uji heterokedastisitas bertujuan untuk menguji apakah dalam model regresi terjadi ketidaksamaan variance dari residual satu pengamatan ke pengamatan lainnya. Jika variance dari residual satu pengamatan ke pengamatan lainnya tetap, maka disebut homokedastisitas. Model regresi yang baik adalah yang homokedastisitas dan tidak terjadi heterokedastisitas (Gujarati, 2004:390). Uji Heterokedastisitas dalam penelitian ini menggunakan Uji Park. Berdasarkan uji heterokedastisitas dengan menggunakan Uji Park tersebut di atas, nilai sig lebih besar dari 0,05, sehingga tidak terjadi heterokedastisitas. 
Tabel 4.5 Uji Park

\begin{tabular}{|c|c|c|c|c|c|}
\hline \multirow[b]{2}{*}{ Model } & \multicolumn{2}{|c|}{ Unstandardized Coefficients } & \multirow{2}{*}{$\begin{array}{c}\text { Standardized } \\
\text { Coefficients }\end{array}$} & \multirow[b]{2}{*}{$\mathrm{t}$} & \multirow[b]{2}{*}{ Sig. } \\
\hline & B & Std. Error & & & \\
\hline 1 (Constant) & .042 & .167 & & 3.253 & .212 \\
\hline $\begin{array}{l}\text { Jumlah Dewan Komisaris } \\
\text { Independen }\end{array}$ & .019 & .049 & .072 & .384 & .703 \\
\hline $\begin{array}{l}\text { Jumlah Rapat Dewan } \\
\text { Komisaris }\end{array}$ & .002 & .001 & .698 & 2.567 & .014 \\
\hline $\begin{array}{l}\text { Jumlah Dewan Pengawas } \\
\text { Syariah }\end{array}$ & -.017 & .014 & -.231 & -1.247 & .218 \\
\hline $\begin{array}{l}\text { Jumlah Rapat Dewan } \\
\text { Pengawas Syariah }\end{array}$ & -.003 & .002 & -.174 & -1.220 & .22 \\
\hline Latar Belakang DPS & -.572 & .447 & -.332 & -1.278 & .208 \\
\hline Jumlah Komite Audit & .000 & .007 & -.009 & -.058 & .954 \\
\hline $\begin{array}{l}\text { jumlah Rapat KOmite } \\
\text { Audit }\end{array}$ & -.003 & .002 & -.240 & -1.207 & .234 \\
\hline
\end{tabular}

\subsection{Pembahasan dan Hasil Pengujian}

Pengujian hipotesis dilakukan dengan analisa regresi berganda dengan metode enter setelah sebelumnya di lakukan pengujian asumsi klasik. Alat analisis yang digunakan adalah SPSS.Nilai adjusted R-square $45,8 \%$ berarti bahwa $45,8 \%$ variasi tax avoaidance dapat dijelaskan oleh variasi variabel independen yaitu Proporsi Komisaris Independen, Jumlah Rapat Dewan Komisaris, Ukuran Dewan Pengawas Syariah, Latar Belakang Pendidikan Dewan Pengawas Syariah, Jumlah Rapat Dewan Pengawas Syariah, Ukuran Komite Audit, Jumlah Rapat Komite Audit sedangkan sisanya yaitu 54,2\% dijelaskan oleh variabel lain di luar model. Uji Anova atau $\mathrm{F}$ test pada tabel menghasilkan nilai $\mathrm{F}$ hitung 2,164 dengan tingkat probabilitas signifikansi 0,006. Probabilita signifikansi jauh lebih kecil dari 0,05, maka model dapat digunakan untuk memprediksi variabel Tax avoaidance, atau dapat dikatakan bahwa variabel Proporsi Komisaris Independen, Jumlah Rapat Dewan Komisaris, Ukuran Dewan Pengawas Syariah, Latar Belakang Pendidikan Dewan Pengawas Syariah, Jumlah Rapat Dewan Pengawas Syariah, Ukuran Komite Audit, Jumlah Rapat Komite Audit dapat memprediksi tax avoidance perusahaan.

Proporsi Komisaris Independen dengan nilai koefisien 0,413 (positif) dan signifikansi 0,040 menunjukkan bahwa proporsi Komisaris Independen berpengaruh positif signifikan terhadap Tax Avoidance perbankan sayriah. Nilai signifikansi lebih kecil dari 0,05 sehingga signifikan. Hasil penelitian ini mendukung penelitian yang menunjukkan bahwa proporsi komisaris independen berpengaruh positif terhadap tax avoidance. Temuan penelitian ini adalah semakin besar prosentase variabel komisaris independen yang berasal dari luar perusahaan menuntut manajemen bekerja lebih efektif dalam pengawasan dan pengendalian pengelolaan perusahaan oleh direksi dan manajer, sehingga keberadaan mereka tidak hanya menjadi simbol semata. Hasilnya kenaikan prosentase dewan komisaris independen terhadap jumlah dewan komisaris secara keseluruhan tidak signifikan mempengaruhi kebijakan tax avoidance yang dilakukan oleh suatu perusahaan. 
Penelitian Antonia (2008) menunjukkan bahwa dewan komisaris independen yang merupakan bagian dari komisaris perseroan tidak melakukan fungsi pengawasan secara baik terhadap manajemen (Kurniasih, 2012). Hal ini memberikan kesempatan bagi manajer untuk melakukan aktivitas manipulasi laba dan nantinya akan menguntungkan perusahaan dalam hal perpajakan.

Ukuran Dewan Pengawas Syariah dengan nilai koefisien 0,116 (positif) dan signifikansi 0,210 menunjukkan bahwa ukuran Dewan Pengawas Syariah tidak berpengaruh positif signifikan terhadap tax avoidance. Nilai signifikansi lebih besar dari 0,05 sehingga tidak signifikan. Hasil penelitian ini tidak sesuai dengan Rahman dan Bukhair (2013). Menurut Nienhaus (2007) dalam Darmadi (2011) bahwa Dewan Pengawas Syariah merupakan pihak independen dalam perbankan yang tidak dapat dipengaruhi oleh manajemen, board of directors dan pemegang saham.

Jumlah Rapat Dewan Pengawas Syariah dengan nilai koefisien 0,009 (positif) dan signifikansi 0,025 menunjukkan bahwa jumlah rapat Dewan Pengawas Syariah berpengaruh positif signifikan terhadap tax avoidance. Nilai signifikansi lebih kecil dari 0,05 sehingga signifikan. Hasil ini sejalan dengan penelitian yang dilakukan oleh Bukair (2014) dan sesuai dengan regulasi tentang jumlah rapat Dewan Pengawas Syariah pada PBI No. 11/33/2009. Menurut Haniffa dan Hudaib (2007) Dewan Pengawas Syariah memainkan peran penting dalam kontrol internal perusahaan dengan tugasnya mereview dan melakukan super visi kegiatan perbankan Islam agar sesuai dengan prinsip-prinsip syariah. Menurut Darmadi (2011) pengungkapan tentang Dewan Pengawas Syariah pada tahun 2010 masih sangat rendah. Rata-rata indeks pengungkapan tentang Dewan Pengawas Syariah sebesar 0,61. Hal ini berbeda dengan apa yang diharapkan di mana Bank Islam di Indonesia mengungkapkan secara jelas deskripsi tentang anggota Dewan Pengawas Syariah, tugas dan tanggung jawab, rapat Dewan Pengawas Syariah, kehadiran Dewan Pengawas Syariah dalam rapat dan remunerasi.

Latar belakang pendidikan Dewan Pengawas Syariah dengan nilai koefisien 0,282 (positif) dan signifikansi 0,045 menunjukkan bahwa latar belakang pendidikan Dewan Pengawas Syariah berpengaruh positif signifikan terhadap tax avoidance. Nilai signifikansi lebih kecil dari 0,05 sehingga signifikan. Hasil ini sesuai dengan penelitian yang telah dilakukan oleh Farook (2011). Dewan Pengawas Syariah yang bereputasi memiliki pengetahuan dan pengalaman yang lebih baik akan mendorong pada peningkatan fungsi monitoring. Namun apabila reputasi Dewan Pengawas Syariah dikaitkan dengan kesibukannya sehingga tidak mampu melakukan fungsinya dengan baik, maka monitoring yang dilakukan akan melemah. Rubin dan Segal (2011) mendokumentasikan bahwa semakin bereputasi maka fungsi monitoringnya akan semakin baik pada 1500 perusahaan yang diambil dari S\&P selama periode 1996-2009.

Jumlah Rapat Dewan Komisaris dengan nilai koefisien 0,003 (positif) dan signifikansi 0,073 menunjukkan bahwa jumlah meeting Dewan komisaris berpengaruh positif signifikan terhadap kualitas pengungkapan laporan perusahaan. Nilai signifikansi lebih kecil dari 0,10 sehingga signifikan. Hasil penelitian ini sesuai dengan Ntim dan Osei (2011). Rapat yang merupakan proses monitoring dan controlling dari Dewan Komisaris mendukung tindakan agresif untuk melakukan tax avoidance. Melalui rapat Dewan Komisaris mengetahui dengan pasti jumlah pajak yang dibayar, sedangkan biaya agency yang muncul untuk menurunkan konflik agency menyebabkan keuntungan perusahaan dengan meminimalkan pajak dengan melakukan tax avoidance. 
Ukuran Komite Audit dengan nilai koefisien 0,014 (positif) dan signifikansi 0,006 menunjukkan bahwa ukuran Komite Audit berpengaruh positif signifikan terhadap tax avoidance. Nilai signifikansi lebih kecil dari 0,05 sehingga signifikan.. Jika jumlah komite audit dalam suatu perusahaan tidak sesuai dengan peraturan BEI maka akan meningkatkan tindakan manajemen dalam melakukan minimalisasi laba untuk kepentingan pajak (Pohan, 2008). Komite audit berfungsi memberikan pandangan mengenai masalah-masalah yang berhubungan dengan kebijakan keuangan, akuntansi dan pengendalian internal perusahaan. Winarsih (2014) dalam penelitiannya menjelaskan bahwa keberadaan komite audit yang fungsinya untuk meningkatkan integritas dan kredibilitas pelaporan keuangan tidak dapat berjalan dengan baik apabila tidak ada dukungan dari seluruh elemen dari dalam perusahaan. Anngota komite audit dengan keahlian akuntansi atau keuangan lebih mengerti celah dalam peraturan perpajakan dan cara untuk menghindari resiko deteksi, sehingga dapat memberi saran yang berguna untuk melakukan penghindaran pajak dan mengahsilkan keuntungan lebih besafr bagi pemegang saham (Rizal : 2015)

Jumlah rapat Komite Audit dengan nilai koefisien 0,002 (positif) dan signifikansi 0,014 menunjukkan bahwa jumlah meeting Komite Audit berpengaruh positif signifikan terhadap kualitas pengungkapan laporan perusahaan. Nilai signifikansi lebih kecil dari 0,05 sehingga signifikan.. Menurut Klein (1998) Komite Audit membantu mengatasi agensi problem dengan meyakinkan bahwa informasi akuntansi akurat dan tidak bias serta diberikan tepat waktu pada pemegang saham, kreditor, dan pihak lain yang berkepentingan dengan perusahaan. Hal ini sejalan dengan Chapra dan Ahmed (2002) bahwa keberadaan internal kontrol yang efektif sangat penting bagi perusahaan keuangan Islam untuk meyakinkan pelaksanaan manajemen dan budaya sehat pada organisasi. Mereka menyatakan pula bahwa posisi auditor internal seharusnya kuat dan independen dan seharusnya memberikan laporan keuangan yang tepat. Dengan melakukan banyak rapat oleh Komite Audit sehingga membantu mengontrol manajer agar berlaku sesuai kepentingan perusahaan.

\section{E. Simpulan}

Berdasarkan pembahasan pengujian hipotesis, maka dapat disimpulkan bahwa:

1. Proporsi Komisaris Independen berpengaruh positif signifikan terhadap tax avoidance

2. Jumlah Rapat Dewan Komisaris tidak berpengaruh signifikan terhadap tax avoidance

3. Ukuran Dewan Pengawas Syariah berpengaruh positif signifikan terhadap tax avoidance

4. Jumlah Rapat Dewan Pengawas Syariah ber pengaruh positif signifikan terhadap tax avoidance

5. Latar belakang pendidikan Dewan Pengawas Syariah berpengaruh positif signifikan terhadap tax avoidance

6. Ukuran Komite Audit berpengaruh positif signifikan terhadap tax avoidance

7. Jumlah Rapat Komite Audit berpengaruh positif signifikan terhadap tax avoidance

\section{DAFTAR PUSTAKA}

Ardiansyah, Rizal. 2017. Pengaruh Good Corporate Governnace dan prifitabilitas terhadap Tax AvoidancePerbankan Syariah Indonesia 2011-2015. UIN Syarif Hidayatullah 
Bhatti, M. and Bhatti,I.(2010), "Toward understanding Islamiccorporate governance issuesinlslamic finance", Asian Politics and Policy, Vol. 2 No. 2, pp. 25-38.

Chapra, M. U. \& Ahmed, H. 2002. Corporate Governance in Islamic Financial Institutions. Islamic Development Bank-Islamic Research and Training Institute. Jeddah.

Chen, K. Y \& Zhou, J. 2007. Audit Committee, Board Cha racteristics and Auditor Switch Decisions by Anderson's Clients. Contemporary Accounting Research, 24 (4): 10851117.

Desai, Mihir A. (2005). Corporate Tax avoidance and Firm Value. National Bureau Of Economic Research. Cambridge

Endraswati, H. (2017). Struktur Islamic Corporate Governance Dan Kualitas Pengungkapan Laporan Keuangan Pada Bank Syariah Di Indonesia Perspektif Governance dan Finance. LP@M IAIN SALATIGA, 15.

Endraswati, Hikmah. 2016. Konsep Awal Islamic Corporate Governance: Peluang Penelitian yang Akan Datang. Muqtashid

Ghozali, Imam. 2009. Aplikasi Analisis Multivariate dengan Program SPSS. Edisi Keempat. Semarang: Badan Penerbit Universitas Diponegoro.

Haniffa, R. \& Hudaib, M. 2007. Exploring the Ethical Identity of Islamic Banks via commmunication in An nual Reports. Journal of Business Ethics, Vol. 76: 97-116.

Hassan, Nik Mustapha Hj Nik. Saifuddeen, Shaikh Mohd. \& Salleh, Shaikh Mohd. 2002. Corporate Governance from the Islamic Perspectives. Kuala Lumpur, Malaysia: Institute of Islamic Understanding

I Gede Hendy Darmawan. (2014). Pengaruh Penerapan Corporate Governance, Leverage, Return On Assets, Dan Ukuran Perusahaan Pada Penghindaran Pajak. E-Jurnal Akuntansi Universitas Udayana, 8556.

Jensen and Meckling. (1976). theory of The Firm : Managerial Behavior, Agency Cost and Ownership Structure. Jounal of financia; Economics 3 (4), 305-360. Journal of accounting Research 1, 28-38.

Klein, A. 1998. Firm performance and board committee structure. Journal of Law and Economics, Vol. 41 (1): 275-303.

Komite Nasional Kebijakan Governance (KNKG). Pedoman Umum Good Corporate Governance. Jakarta : KNKG, 2006

Kurniasih, N. A. (2012). Pengaruh Corporate Governance Terhadap Tax Avoidance . Jurnal akuntansi dan Auditing, 95-189.

Loredana, Dan Roxana. Alexandru, Buglea. \& Roxana, Hetes. 2016. Comparative Analysis Between The Traditional Model of Corporate Governance and Islamic Model. Economy Series. Academica Brancusi Publisher. University of Targu Jiu.

Rahman, Azhar Abdul \& Bukhair Abdullah A. 2013. The Influence of the Shariah Supervision Board on Corporate Social Responsibility Disclosure by Islamic Banks of Gulf CoOperation Council Countries Asian. Journal of Business and Accounting, 6(2).

Rubin, Amir. \& Segal, Dan. 2011. Board Reputation and Financial Reporting Quality. Working Paper. Singapore Management University.

Rama, Ali. \& Novella, Yella. 2015. Shariah Governance dan Kualitas Tata Kelola Perbankan Syariah. Signifikan, Vol. 4(2): 111-127.

Sandy, dan Niku Luviarman. 2015. Pengaruh Corporatae Governance terhadap Tax Vaoidance : Studi Empiris pada Perusahaan Manufaktur. JAAI Voulne 19 No 2, FDesember 2015 : 85-98 
Tandean, V. A. (2016). The Effect of Good Corporate Governance on Tax Avoidance: An Empirical Study on Manufacturing Companies Listed in IDX period 2010-2013. Asian

Winarsih, R., Prasetyono, Kusufi, M. S., 2014, Pengaruh Good Corporate Governance dan Corporate Sosial Responsibility Terhadap Tindakan Pajak Agresif: Studi pada Perusahaan Manufaktur yang Listing di BEI Tahun 2009-2012. Simposium Nasional Akuntansi XVII.

https://ekonomi.kompas.com/read/2010/02/02/21183172/tunggakan.pajak.bni.akibat.paja k.berganda. 